\title{
Synthesis of hydrochloric acid solution for total mercury determination in natural waters
}

\author{
Nathalie Patel-Sorrentino ${ }^{\mathrm{a},{ }^{*},}$, Jean-Yves Benaim ${ }^{\mathrm{a}}$, Daniel Cossa $^{\mathrm{b}}$ and Yves Lucas ${ }^{\mathrm{a}}$
}

a Laboratoire PROTEE (Processus de Transferts et d'Echanges dans l'Environnement), Equipe CAPTE, Université du Sud Toulon-Var, BP 20132, 83957 La Garde cedex, France

${ }^{\mathrm{b}}$ Ifremer, Centre de Méditerranée, BP 330, 83507 La Seyne-sur-Mer, France

*: Corresponding author : Nathalie Patel-Sorrentino, Tel.: +33 (0)4 941423 06. Fax : +33 (0)4 9414

21 68. email address : patel@univ-tln.fr

\begin{abstract}
:
Total mercury $\left(\mathrm{Hg}_{\mathrm{T}}\right)$ determination requires the addition of concentrated hydrochloric acid solution $\left(\geq 10 \mathrm{~mol} \mathrm{~L}^{-1} \mathrm{HCl}\right)$ in relatively high amounts to preserve the samples and to prepare reagent solutions. A method for the preparation of concentrated $\mathrm{HCl}$ with $\mathrm{Hg}_{\mathrm{T}}$ concentration of lower than $5 \mathrm{ng} \mathrm{L}^{-1}$ is described in this article. It is based on the well-known chemical reaction: $2 \quad \mathrm{NH}_{4} \mathrm{Cl}+\mathrm{H}_{2} \mathrm{SO}_{4}$ $\rightarrow\left(\mathrm{NH}_{4}\right)_{2} \mathrm{SO}_{4}+2 \mathrm{HCl}$. This method is validated thanks to the US Environmental Protection Agency method 1631 and standard reference materials BCR-579 (mercury in coastal seawater).
\end{abstract}

Keywords: Synthesis - Hydrochloric acid - Mercury determination - Green analytical chemistry 


\section{Introduction}

Considering the very low concentrations of mercury $(\mathrm{Hg})$ in natural waters $(0.05-$ $5.00 \mathrm{ng} \mathrm{L}^{-1}$ ), important loss and contamination problems can arise in sampling, sampling treatment and analysis processes [1-7]. The main mercury loss is due to $\mathrm{Hg}$ adsorption on bottle walls, but it is now recognized that the addition of acid (e.g. $\mathrm{HCl})$ or oxidant (e.g. $\mathrm{BrCl}$ ) allowed stabilisation of water samples for total dissolved $\mathrm{Hg}$ determination after filtration [4-7]. About contaminations, the routes are numerous and can lead to obtain erroneously high total mercury $\left(\mathrm{Hg}_{\mathrm{T}}\right)$ concentrations [8]. Such errors were common before the 80's and marine chemists have come to recognize that high concentrations were frequently reflecting contamination from sampling and analysis rather than ambient levels [5]. To overcome these analytical difficulties, a standardised sampling and analysis protocol has been proposed with the US Environmental Protection Agency (EPA) method 1631 [5]. During analysis, major problems might arise due to insufficient blank control. The total blank is composed of the system blank which is the total mercury coming from the analytical equipment (carrier gas argon, Teflon tubing, reaction vessel, gold quartz-sand trap, etc) and the reagent blank which is the total mercury coming from the reagent solutions $(\mathrm{HCl}, \mathrm{BrCl}$, $\mathrm{NH}_{2} \mathrm{OH} \cdot \mathrm{HCl}, \mathrm{SnCl}_{2}$ ).

Repeated purging and analysis of pre-purged samples allow the determination of the system blank and its standard deviation. It should be stable and $\leq 10 \mathrm{pg}$, otherwise the system and/or operating variables must be changed.

Beside the system contamination, the reagent blank is determined by analyzing the reagent solutions and should not exceed $20 \mathrm{pg}$ [5]. To preserve the samples and to prepare the reagent solutions, concentrated hydrochloric acid $(\mathrm{HCl})$ solution is added in relatively high amounts to the samples and reagents; it must therefore be of superior quality $[5,9,10]$. High quality $\mathrm{HCl}$ solution is generally purchased at high cost [11-14], or may be obtained by repeated sub-boiling distillation of cheap analytical reagent grade $\mathrm{HCl}$ solution $[1,9,15]$ or by purging analytical reagent grade $\mathrm{HCl}$ solution for at least $12 \mathrm{~h}$ after adding a small quantity of reductant $\mathrm{NaBH} 4$ to it [7]. The purpose of this article is to propose an alternative way synthesising high quality $\mathrm{HCl}$ solutions from low cost analytical reagent grade products. This quick and easy process presents advantages such as (i) a low cost production, (ii) controlled quantity and quality for 'fresh' solutions and (iii) cost and environmental gains if we consider the unused part of the commercial $\mathrm{HCl}$ solution because of the loss of quality due to a bottle which lasts a long time after opening. This environmental benefit is consistent with the green analytical chemistry (GAC) approach $[16,17]$. Indeed, the diminution in the amount of reagents employed in the measurement step is a mean for reducing adverse environmental impact of analytical methodologies in the philosophy of GAC.

\section{Experimental}

\section{Material}

For each synthesised hydrochloric acid solution batch, the concentrations of $\mathrm{HCl}$ and $\mathrm{Hg}_{\mathrm{T}}$ were verified. With regard to the $\mathrm{HCl}$ concentration, a simple acid-base titration by a $\mathrm{pH}$ electrode (Mettler Toledo) and freshly prepared $\mathrm{NaOH}$ solutions was used. $\mathrm{Hg}_{\mathrm{T}}$ concentrations were measured using a Tekran $2500^{\circledR}$ cold vapor atomic fluorescence spectrometer (CVAFS) and gold quartz-sand traps for $\mathrm{Hg}$ pre-concentration. 


\section{Mercury measurements}

$\mathrm{Hg}_{\mathrm{T}}$ determination for freshwater samples is well documented and a large majority of researchers use the US Environmental Protection Agency (EPA) method 1631 [5]. Prior to analysis, all $\mathrm{Hg}$ in a sample aliquot is oxidized to labile $\mathrm{Hg}^{2+}$ with bromine monochloride $(\mathrm{BrCl})$ solution. After oxidation, the sample is sequentially reduced with hydroxylaminehydrochloride $\left(\mathrm{NH}_{2} \mathrm{OH} \cdot \mathrm{HCl}\right)$ solution to neutralize free halogens which can destroy the gold traps, then reduced with an excess of stannous chloride $\left(\mathrm{SnCl}_{2}\right)$ solution to convert $\mathrm{Hg}^{2+}$ to volatile $\mathrm{Hg}^{0}$. Elemental $\mathrm{Hg}$ is purged from solution with $\mathrm{Hg}$-free argon and collected onto a collection gold trap by amalgamation. $\mathrm{Hg}$ is thermally desorbed from this trap into an argon stream that drives the released $\mathrm{Hg}^{0}$ to the analytical gold trap. The $\mathrm{Hg}$ is thermally desorbed from the analytical trap into an argon stream that carries $\mathrm{HgO}$ vapor into the cell of an atomic fluorescence spectrometer. The analytical procedure used both for analysis of the synthesised $\mathrm{HCl}$ solution and the reference material has followed the method described here and detailed by Cossa et al. [14].

\section{Reagent solutions}

The argon used as a carrier gas is Argon Instrument 5.0 (99.999\%, Linde Gas) which has been $\mathrm{Hg}$ purified by passing through a gold quartz-sand trap. All the Teflon material used for the synthesis of hydrochloric solutions was perfluoroalkoxy (PFA) Teflon.

At first, to test the $\mathrm{Hg}_{\mathrm{T}}$ concentration in the synthesised $\mathrm{HCl}$ solution and validate our method, concentrated $\mathrm{HCl}(30 \%)$ Suprapur ${ }^{\circledR}$ solution (Merck) was used for the reagents preparation. Moreover the $\mathrm{Hg}_{\mathrm{T}}$ concentration was measured in this commercial solution to compare to our synthesized $\mathrm{HCl}$ solution.

$\mathrm{Hg}_{\mathrm{T}}$ determination requires the preparation of the stannous chloride $\left(\mathrm{SnCl}_{2}\right)$, hydroxylaminehydrochloride $\left(\mathrm{NH}_{2} \mathrm{OH} \cdot \mathrm{HCl}\right)$ and bromine monochloride $(\mathrm{BrCl})$ solutions. These reagent solutions were carried out as described by Cossa et al. [14].

After preparation, the solutions were stored in Teflon bottles tightly capped, double-bagged in new polyethylene zip-type bags and stored in a cold $\left(\leq 4{ }^{\circ} \mathrm{C}\right)$ and dark place in a plastic box until use.

\section{Cleaning}

The Teflon material used for the synthesis of $\mathrm{HCl}$ solution was cleaned by heating to $60-70{ }^{\circ} \mathrm{C}$ in $4 \mathrm{M} \mathrm{HCl}$ for at least $12 \mathrm{~h}$. The material was cooled, rinsed ten times with deionised water, and dried in a $\mathrm{Hg}$-free clean bench just before use.

\section{Synthesis of hydrochloric acid solution}

The $\mathrm{HCl}$ solution was synthesised using the well known industrial process: 2 $\mathrm{NH}_{4} \mathrm{Cl}+\mathrm{H}_{2} \mathrm{SO}_{4} \rightarrow\left(\mathrm{NH}_{4}\right)_{2} \mathrm{SO}_{4}+2 \mathrm{HCl}$, with an extreme care to avoid $\mathrm{Hg}$ contamination. The best way is to minimize exposure to ambient contamination including: (i) the use of a laminar flow hood equipped with a charcoal filter, (ii) wearing gloves and (iii) the use of metal-free and well cleaned material.

In the process, $20 \mathrm{~mL} \mathrm{H}_{2} \mathrm{SO}_{4}(\mathrm{MM}=98.07 \mathrm{~g}$ mol-1; $\mathrm{d}=1.83 ; 95 \%$ for analysis, Fisher Scientific) react with $20 \mathrm{~g} \mathrm{NH} 4 \mathrm{Cl}$ (MM $=53.49 \mathrm{~g} \mathrm{~mol}-1 ; 99.5 \%$ for analysis, Fisher Scientific) to produce $\mathrm{HCl}$ gas which is dissolved in $20 \mathrm{~mL}$ of deionised water. The $\mathrm{H} 2 \mathrm{SO} 4$ was put in a Teflon recipient $(30 \mathrm{~mL}$, Savillex®) and brought to the Teflon reaction flask $\left(120 \mathrm{~mL}\right.$, Savillex $\left.{ }^{\circledR}\right)$ containing the $\mathrm{NH}_{4} \mathrm{Cl}$ thanks to a peristaltic pump (Gilson ${ }^{\circledR}$ ) (Fig. 1). The Teflon reaction flask was equipped with a 
two ports transfer cap; one port was connected to the $\mathrm{H}_{2} \mathrm{SO}_{4}$ flask via the peristaltic pump, the other to the Teflon recipient $\left(30 \mathrm{~mL}\right.$, Savillex $\left.{ }^{\circledR}\right)$ containing the deionised water which received the $\mathrm{HCl}$ vapour. To avoid over pressure, this Teflon recipient was not hermetically closed but protected with a Parafilm ${ }^{\circledR}$ sheet and a polyethylene zip-type bag. Connections consisted of PFA Teflon tubings and a Viton ${ }^{\circledR}$ tubing for the peristaltic pump. The $\mathrm{H} 2 \mathrm{SO} 4$ flow was adjusted to 0.1 $\mathrm{mL}$ min-1. This low flow was required to carry out a correct dissolution of the $\mathrm{HCl}$ gas into the deionised water in order to give a concentrated $\mathrm{HCl}$ solution. These process conditions allow obtaining about $27 \mathrm{~mL} \mathrm{HCl}$ within 4 hours with a yield going from $82 \%$ to $87 \%$ depending on the batches.

\section{Results and discussion}

The total mercury background concentration in ocean water is around $0.05-2.00$ $n g L^{-1}[2,4]$, which represents, for a $100 \mathrm{~mL}$ sample usually collected for $\mathrm{Hg}_{\mathrm{T}}$ determination, a $\mathrm{Hg}_{\mathrm{T}}$ amount of 5-200 pg. The $\mathrm{Hg}_{\mathrm{T}}$ contamination due to the necessary use of $\mathrm{HCl}$ solution (sample preservation and reagent preparation) is estimated as follows. It as already been shown that $\mathrm{Hg}_{\mathrm{T}}$ is stable for long-term storage when samples are kept in the dark and acidified with $0.4-0.5 \% \mathrm{HCl}(\mathrm{v} / \mathrm{v})$ $[4,5,13,14]$. With a superior quality $\mathrm{HCl}$ solution having a $5 \mathrm{ng} \mathrm{L^{-1 }} \mathrm{Hg}_{\mathrm{T}}$ concentration, as recommended [5], such an add represents a 2-3 pg $\mathrm{Hg}_{\mathrm{T}}$ amount for a $100 \mathrm{~mL}$ sample. When using the same $\mathrm{HCl}$ solution to prepare the reagent solutions, the $\mathrm{Hg}_{\mathrm{T}}$ contaminations coming from the $\mathrm{HCl}$ solution are 0.5 $\mathrm{ng} \mathrm{L^{-1 }}, 0.1 \mathrm{pg} \mathrm{L}^{-1}$ and $4 \mathrm{ng} \mathrm{L}^{-1}$ for $\mathrm{SnCl}_{2},\left(\mathrm{NH}_{2} \mathrm{OH} \cdot \mathrm{HCl}\right)$ and $\mathrm{BrCl}$ solutions respectively. To carry out the $\mathrm{Hg}_{\mathrm{T}}$ determination, $0.5 \% \quad(\mathrm{v} / \mathrm{v})$ bromine monochloride solution, $0.2 \%(\mathrm{v} / \mathrm{v})$ hydroxylamine hydrochloric solution and $0.5 \%$ ( $\mathrm{v} / \mathrm{v})$ stannous chloride solution must be added to the sample [5, 14]. Therefore, considering a $100 \mathrm{~mL}$ sample, the amount of $\mathrm{Hg}_{\mathrm{T}}$ coming from a $5 \mathrm{ng} \mathrm{Hg} \mathrm{\textrm {L } ^ { - 1 } \mathrm { HCl }}$ solution, represents around $20 \mathrm{pg}$. If the purging of reducting reagent solutions, $\mathrm{SnCl}_{2}$ and $\left(\mathrm{NH}_{2} \mathrm{OH} \cdot \mathrm{HCl}\right)$ with $\mathrm{Hg}$-free argon can reduce $\mathrm{Hg}_{\mathrm{T}}$ to acceptable levels, it is not the case for $\mathrm{BrCl}$ because it is an oxidant solution. However, the $\mathrm{KBrO}_{3}$ and $\mathrm{KBr}$ can be purified by heating them to $250{ }^{\circ} \mathrm{C}$ for a minimum of $12 \mathrm{~h}$ [14]. Hence, it is obvious that one of the main key to avoid $\mathrm{Hg}$ contamination during the preservation and the analysis processes is to use the mostly $\mathrm{Hg}$-purified $\mathrm{HCl}$ solution.

The $\mathrm{HCl}$ concentrations and total mercury concentrations were measured for (i) a concentrated $\mathrm{HCl}(30 \%)$ Suprapur ${ }^{\circledR}$ solution (Merck) issued from a just-opened bottle and (ii) the here synthesised $\mathrm{HCl}$ solutions. Results are shown in Table 1.

The results regarding $\mathrm{Hg}_{T}$ concentrations were validated by investigation of the standard reference material BCR-579. This sample with a certified mercury value of $1.9 \pm 0.5 \mathrm{ng} \mathrm{Hg} \mathrm{kg}{ }^{-1}(\mathrm{n}=6)$ consists of acidified coastal seawater. It was analysed with the described method and a mean value of $2.0 \pm 0.5 \mathrm{ng} \mathrm{Hg} \mathrm{kg}^{-1}$ (n = 5) was obtained.

This study shows the following results: (i) both types of $\mathrm{HCl}$ solutions (commercial and synthesised) are concentrated acid solutions; (ii) it confirms that the concentrated $\mathrm{HCl}(30 \%)$ Suprapur ${ }^{\circledR}$ solution (Merck) is a high purity grade; (iii) it proves that the $\mathrm{HCl}$ solution synthesised by the proposed method is almost $\mathrm{Hg}$ free even when prepared with low grade products which are potentially $\mathrm{Hg}$ contaminated. Reaction between $\mathrm{NH} 4 \mathrm{Cl}$ and $\mathrm{H} 2 \mathrm{SO} 4$ occurs in a non reducing environment making the presence of volatile reduced $\mathrm{Hg}$ species unlikely. The lower volatility of the oxidized $\mathrm{Hg}$ species limits its transfer within the $\mathrm{HCl}$ gas stream produced by the reaction, even with low grade reagents. 


\section{Conclusion}

The synthesis described in this article allows quick, cheap and easy obtaining of concentrated $\mathrm{HCl}$ solutions having $\mathrm{Hg}_{\mathrm{T}}$ concentration $<5 \mathrm{ng} \mathrm{L}^{-1}$, value which corresponds to the grade concentration recommended by the literature for total mercury analysis. Key advantages of this alternative way to have $\mathrm{HCl}$ solutions of superior quality are the following. First, costs for a given quantity are at least 2 times less than the purchase of a Suprapur ${ }^{\circledR}$ grade $\mathrm{HCl}$ solution. It can even cost 25 times less if highly pure commercial solutions are considered. Secondly, this synthesis allows always having 'fresh' solutions with controlled qualities $(\mathrm{HCl}$ concentration and almost $\mathrm{Hg}$-free) and quantities. The usual minimum amount of commercial concentrated Suprapur ${ }^{\circledR}$ grade $\mathrm{HCl}$ solution is $250 \mathrm{~mL}$ when the required quantities for total mercury analysis are small, so that a given bottle lasts a long time after opening, increasing the risks of $\mathrm{HCl}$ concentration loss and $\mathrm{Hg}$ contamination. Thirdly, if we consider the unused part of a commercial $\mathrm{HCl}$ solution, because of the loss of quality once the container is opened, the synthesis of the exact required quantity increases the cost gain but also becomes an environmental benefit. It corresponds to the philosophy of GAC by decreasing the amounts of consumed reagents.

\section{Acknowledgments}

The authors wish to thank to D.H. Dang for his help in the drawing of the figure.

\section{References}

1. Fadini PS, Jardim WF (2000) Analyst 125:549-551

2. Gill GA, Fitzgerald WF (1985) Deep-Sea Res Pt A 32:287-297

3. Bloom NS (1995) Environ Lab 7:20-26

4. Parker JL, Bloom NS (2005) Sci Total Environ 337:253-263

5. US Environmental Protection Agency (2002) Method 1631, Revision E: Mercury in Water by Oxidation, Purge and Trap, and Cold Vapor Atomic Fluorescence Spectrometry, EPA 821-R-02-019

6. Logar M, Horvat M, Akagi H, Pihlar B (2002) Anal Bioanal Chem 374:10151021

7. Leopold K, Foulkes M, Worsfold P (2010) Anal Chim Acta 663:127-138

8. Fitzgerald RA, Gordon Jr DC, Cranston RE (1974) Deep Sea Res and Oceanographic Abstracts 21:139-144

9. Brügmann L (1999) In: Grasshoff K, Kremling K, Ehrhardt M (ed) Methods of Seawater Analysis, 3rd edn. Wiley-VCH, Weinheim

10. Cai Y (2000) Trends Anal Chem 19:62-66

11. Taylor VF, Jackson BP, Chen CY (2008) Anal Bioanal Chem 392:1283-1290

12. Bloom NS, Crecelius EA (1983) Mar Chem 14:49-59

13. Quemerais B, Cossa D (1995) Protocoles d'Echantillonnage et d'Analyses du Mercure dans les Eaux Naturelles, Rapport Scientifique et Technique ST-31, Québec

14. Cossa D, Averty B, Bretaudeau J, Sénard AS (2003) Spéciation du Mercure Dissous dans les Eaux Marines. Ifremer, Brest

15. Hinn GM, Nelson BK (1997) Nucl Instr and Meth in Phys Res A 397:189-193

16. Armenta S, Garrigues S, De la Guardia M (2008) Trends Anal Chem 27:497511

17. Tobiszewski M, Mechlinska A, Zygmunt B, Namiesnik J (2009) Trends Anal Chem 28:943-951 


\section{Figures}

Fig. 1 Schematic of the experimental protocol for the $\mathrm{HCl}$ synthesis

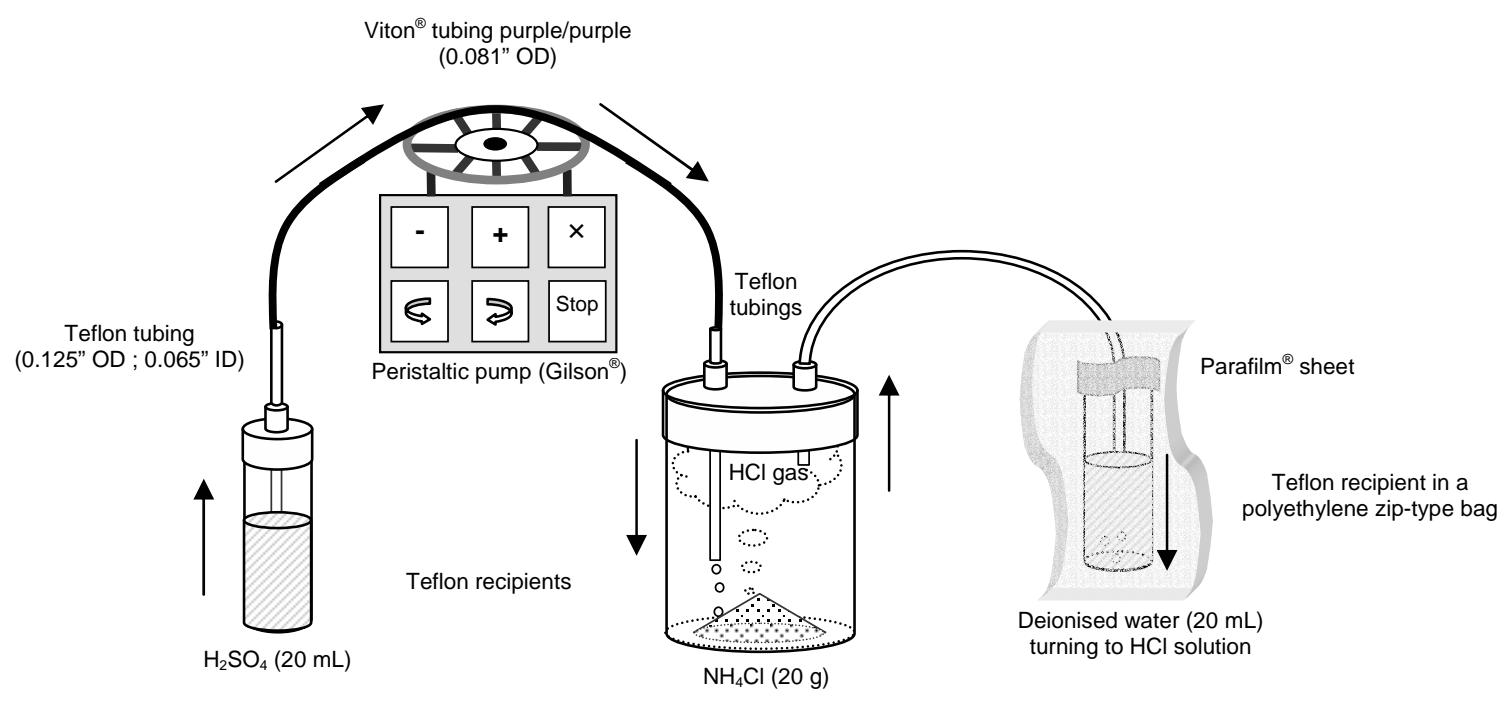

Tables

Table $1 \mathrm{HCl}$ and total mercury concentrations for commercial and synthesised $\mathrm{HCl}$ solutions

\begin{tabular}{l|c|cccc}
\hline HCl solution & $\begin{array}{c}{[\mathrm{HCl}]} \\
\left(\mathbf{m o l ~ L}^{-}\right. \\
\mathbf{1})\end{array}$ & $\begin{array}{c}{\left[\mathrm{Hg}_{\mathrm{T}}\right]} \\
\text { range } \\
\left(\mathbf{n g ~ L}^{-1}\right)\end{array}$ & $\begin{array}{c}{\left[\mathrm{Hg}_{\mathrm{T}}\right]} \\
\text { mean } \\
\left(\mathbf{n g ~ L}^{-1}\right)\end{array}$ & $\begin{array}{c}\text { Standard } \\
\text { deviation } \\
\left(\mathbf{n g ~ L}^{-1}\right)\end{array}$ & $\begin{array}{c}\text { Number of } \\
\text { determination }\end{array}$ \\
\hline $\begin{array}{l}\text { Suprapur } \\
\text { (®) }\end{array}$ & 10.0 & $\begin{array}{c}1.32- \\
1.44\end{array}$ & 1.38 & 0.05 & 5 \\
$\begin{array}{l}\text { Synthesised } \\
\text { batch 1 }\end{array}$ & 12.2 & $\begin{array}{c}0.57- \\
0.68\end{array}$ & 0.64 & 0.04 & 5 \\
$\begin{array}{l}\text { Synthesised } \\
\text { batch 2 }\end{array}$ & 11.9 & $\begin{array}{c}0.18- \\
0.31\end{array}$ & 0.24 & 0.05 & 5 \\
$\begin{array}{l}\text { Synthesised } \\
\text { batch 3 }\end{array}$ & 11.8 & $\begin{array}{c}0.60- \\
0.73\end{array}$ & 0.66 & 0.04 & 5 \\
$\begin{array}{l}\text { Synthesised } \\
\text { batch 4 }\end{array}$ & 12.0 & $\begin{array}{c}0.46- \\
0.56\end{array}$ & 0.51 & 0.05 & 5 \\
$\begin{array}{l}\text { Synthesised } \\
\text { batch 5 }\end{array}$ & 11.8 & $\begin{array}{c}0.22- \\
0.31\end{array}$ & 0.27 & 0.05 & 5 \\
\hline
\end{tabular}

